\title{
The Effect of Cutting Parameters on Tool Wear During the Milling of Carbon Fiber Reinforced Polymer (CFRP) Composites
}

\author{
Dervis OZKAN ${ }^{1}$ *, Mustafa Sabri GOK ${ }^{2}$, Hasan GOKKAYA ${ }^{3}$, \\ Abdullah Cahit KARAOGLANLI ${ }^{4}$
}

\author{
${ }^{1}$ Bartin University, Department of Mechanical Engineering, 74110, Bartin, Turkey \\ ${ }^{2}$ Bartin University, Department of Mechanical Engineering, 74110, Bartin, Turkey \\ ${ }^{3}$ Karabuk University, Department of Mechanical Engineering, 78050, Karabuk, Turkey \\ ${ }^{4}$ Bartin University, Department of Metallurgical and Materials Engineering, 74110, Bartin, Turkey
}

crossref http://dx.doi.org/10.5755/j01.ms.25.1.19177

Received 01 October 2017; accepted 15 January 2018

\begin{abstract}
Reduction of machining times and optimization of cutting parameters and conditions hold great importance in machining processes. Milling is among the most important machining processes used for machining of fiber-reinforced composite materials. The present research was carried out to investigate the effect of cutting parameters on tool wear during the milling of carbon fiber reinforced polymer (CFRP) materials which are widely used in aviation and aerospace industries. A multi-directional CFRP composite material with $6 \mathrm{~mm}$ width and 26 layers was used as the workpiece. The tests were performed under dry conditions on a CNC vertical processing center with 100,200 and $300 \mathrm{~m} / \mathrm{min}$ cutting speeds; $0.05,0.15$ and $0.25 \mathrm{~mm} /$ tooth feedrates and at $1 \mathrm{~mm}$ constant cutting width. To understand the wear process, scanning electron microscopy (SEM) analyses of the worn surfaces were performed.

Keywords: carbon fiber reinforced polymer (CFRP), edge milling, tool wear, and carbide tools.
\end{abstract}

\section{INTRODUCTION}

Owing to their light structure with high strength and corrosion resistance, Carbon Fiber Reinforced Polymer (CFRP) composites are widely used in military, automotive and aerospace industries [1-3]. On the other hand, these materials are classified as difficult-to-machine materials due to their low thermal conductivity and abrasive nature [4, 5]. Tool wear arising during the machining of CFRP composites lead to problems such as delamination, fiber-matrix debonding, surface roughness, fiber breakage and uncut fibers, which in turn result in a reduced surface quality for the machined workpiece [6].

Due to their main properties, machining of CFRP composites is achieved by means of milling operation which is among the traditional manufacturing methods. However, there are numerous factors can affect the milling of composites [7-9]. Accordingly, the necessity of machining CFRP composites with sharp cutting tools arises, which also requires the use of optimum cutting parameters, particularly feedrate. Crushing of workpiece by cutting tool, fiber debonding and consequently occurring delamination can be averted by correct choice of feedrate [10-12]. Hagino and Inoue [1], edge milled CFRP composites with different fiber orientation angles. In their research they used end mills with three different helix angles $\left(0^{\circ}-30^{\circ}-45^{\circ}\right)$ and observed negligible levels of flank wear, and scratches on the flank surfaces of all tools. The tool with $0^{\circ}$ helix angle was reported to be effective in the machining of CFRP composites, as indicated by negligible flank wear obtained from all tools. Rusinek [13]

\footnotetext{
* Corresponding author. Tel.: +90 378-5011000 / 1624: +90-3785011021. E-mail address: dervisozkan@bartin.edu.tr (D. Ozkan)
}

investigated the relationship between cutting forces and cutting parameters in the milling of CFRP composites using diamond coated end mill at different cutting speeds and feedrates. According to the research results, low feedrates resulted with better tool life, whereas increased feedrates also increased the cutting forces. Suitable cutting speeds were reported to reduce the vibration and minimize the cutting force. Karpat and Polat [14] used two different pairs of end mills (diamond coated carbide) to machine CFRP composites. During the tests they used a workpiece with two different fiber orientation angles and different layer widths. Feedrates were chosen as 0.015, 0.02 and $0.025 \mathrm{~mm} /$ tooth, cutting speed as $3500 \mathrm{rev} / \mathrm{min}$ and cutting width as $3 \mathrm{~mm}$. Edge rounding and tool breakage were detected on the diamond coated tool due to the abrasive characteristic of carbon fibers. Chatelain et al. [15], investigated the effect of cutting speed and feedrate on surface roughness, during the machining of CFRP composite material with double-sided PCD milling cutter. They reported that, during the tests they applied high cutting speeds and low feedrates to obtain a good surface quality. Nor Khairusshima et al. [16] investigated the effect of cutting parameters on cutting tool and surface quality in milling of CFRP composites. They used a double-sided carbide shoulder milling cutter with $8 \mathrm{~mm}$ diameter and $30^{\circ}$ helix angle to mill a workpiece with $0^{\circ} / 45^{\circ}$ fiber orientation angle. They reported reduced levels of tool wear as a result of increased cutting speed and reduced feedrate. The shortcomings encountered during machining of CFRP composites can be overcome through correct selection of cutting tool geometry and material. In cutting tools, sharpness of the cutting edge holds great importance for machining of CFRP composites. During the machining, high precision can be 
achieved through a correct selection of tool geometry (sharp edged) and cutting parameters to reduce the compressive forces exerted on the tool and workpiece [17, 18]. In this study, the effect of three different cutting speeds and feedrates as machining parameters on milling of CFRP composite workpiece with WC-Co carbide tools and the resultant tool wear were investigated. The resultant wear on cutting tools after the machining process was evaluated using scanning electron microscope (SEM).

\section{MATERIALS AND METHODS}

CFRP composite material with $\left(0 \%+45^{\circ} / 90^{\circ} /-45^{\circ}\right)_{\mathrm{s}}$ fiber orientation and $140 \times 100 \times 6 \mathrm{~mm}$ dimensions was used as the workpiece during the tests carried out with uncoated carbide tools (Fig. 1). The materials characteristics of the CRFP composite used in milling tests are given in Table 1.

Table 1. Material characteristics of the examined CFRP plate

\begin{tabular}{|l|c|}
\hline Weave type & Twill $2 \times 2$ \\
\hline Fabric weight & $200 \mathrm{gr} / \mathrm{m}^{2}$ \\
\hline Number of plies & 26 \\
\hline Resin type & Epoxy \\
\hline Fiber volume fraction & $50 \%$ \\
\hline Ply thickness in laminate & $\sim 0.2 \mathrm{~mm}$ \\
\hline Number of filaments per roving & $3 \mathrm{~K}$ \\
\hline
\end{tabular}

Contour milling operations performed with uncoated carbide inserts were carried out on a Falco VMC 850-B brand 3-axis CNC vertical processing center with $10 \mathrm{~kW}$ output power. Sandvik Coromant company's uncoated carbide inserts with R390-11 T3 04E-NL H13A product id were used during the tests. Sandvik Coromant's shoulder cutter with id no: R390-025A25-11L was used for mounting the selected inserts (Fig. 1). For maintaining constant cutting conditions, a single insert was mounted on the shoulder cutter throughout the tests. TESCAN brand, MAIA3 XN model SEM was used for taking the images of uncoated carbide inserts.

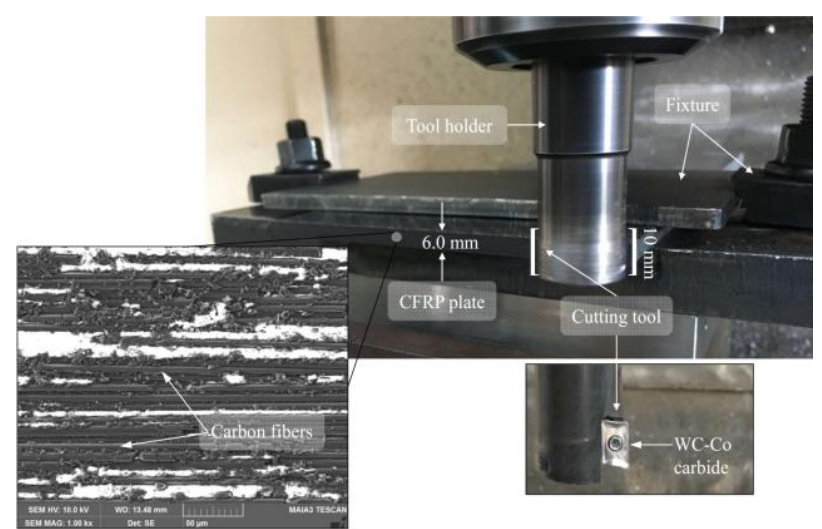

Fig. 1. CFRP composite and experimental set-up

The tests were carried out under dry cutting conditions with different cutting speeds and feedrates using the parameters selected in consideration of the current literature studies. Throughout the tests, only one insert was mounted on the double-sided shoulder cutter with $25 \mathrm{~mm}$ cutting diameter, to maintain a stable cutting condition (Fig. 1). Accordingly, cutting operations were performed with nine different cutting tests; at three different cutting speeds $(100,200$ and $300 \mathrm{~m} / \mathrm{min})$, three different feedrates ( $0.05,0.15$, and $0.25 \mathrm{~mm} /$ tooth), constant axial cutting depth $\left(a_{p}=6 \mathrm{~mm}\right)$ and radial cutting width $\left(a_{e}=1 \mathrm{~mm}\right)$ (Table 2). The factors which are effective on the cutting parameters are cutting speed, feedrate and cutting width.

Table 2. Experimental parameters used in milling tests

\begin{tabular}{|c|c|c|}
\hline Exp. & $V_{c}, \mathrm{~m} / \mathrm{min}$ & $f_{z}, \mathrm{~mm} /$ tooth \\
\hline $1-4-7$ & 100 & $0.05-0.15-0.25$ \\
\hline $2-5-8$ & 200 & $0.05-0.15-0.25$ \\
\hline $3-6-9$ & 300 & $0.05-0.15-0.25$ \\
\hline
\end{tabular}

\section{RESULTS AND DISCUSSION}

The tool wear values $\left(V_{B}\right)$ obtained with uncoated carbide inserts at three different cutting speeds and feedrates are given in Table 3 . The values were measured from the SEM images after the tenth and twentieth passes. The data were obtained from the middle section of the inserts which are $10 \mathrm{~mm}$ in length. Contour milling operation on the workpiece with $6 \mathrm{~mm}$ thickness was carried out with the contact points $2 \mathrm{~mm}$ above and below (Fig. 1).

Table 3. Test parameters used during the milling tests

\begin{tabular}{|c|c|c|c|c|c|c|}
\hline \multirow{2}{*}{$\begin{array}{c}\text { Cutting } \\
\text { tool }\end{array}$} & \multirow{2}{*}{$\begin{array}{c}\text { Cutting } \\
\text { speed, } \\
\mathrm{m} / \mathrm{min} \\
V_{c}\end{array}$} & \multirow{2}{*}{$\begin{array}{c}\text { Cutting } \\
\text { width, } \\
\mathrm{mm} \\
a_{e}\end{array}$} & \multirow{2}{*}{$\begin{array}{c}\text { Axial } \\
\text { cutting } \\
\text { depth, } \\
\mathrm{mm} \\
a_{p}\end{array}$} & \multirow{2}{*}{$\begin{array}{c}\text { Feed } \\
\text { rate, } \\
\mathrm{mm} / \text { tooth } \\
f_{z}\end{array}$} & \multicolumn{2}{|c|}{$\begin{array}{c}\text { Tool wear, } \mu \mathrm{m} \\
V_{B} \\
\end{array}$} \\
\hline & & & & & $\begin{array}{l}10 . \\
\text { Pass }\end{array}$ & $\begin{array}{c}20 . \\
\text { Pass }\end{array}$ \\
\hline \multirow{9}{*}{$\begin{array}{l}\text { Uncoated } \\
\text { carbide } \\
\text { insert } \\
\text { (Sandvik) }\end{array}$} & \multirow{3}{*}{100} & \multirow{3}{*}{1} & \multirow{3}{*}{6} & 0.05 & 193.5 & 214.4 \\
\hline & & & & 0.15 & 146.5 & 161.6 \\
\hline & & & & 0.25 & 143.3 & 158.3 \\
\hline & \multirow{3}{*}{200} & \multirow{3}{*}{1} & \multirow{3}{*}{6} & 0.05 & 135.0 & 198.0 \\
\hline & & & & 0.15 & 113.7 & 146.3 \\
\hline & & & & 0.25 & 98.6 & 157.4 \\
\hline & \multirow{3}{*}{300} & \multirow{3}{*}{1} & \multirow{3}{*}{6} & 0.05 & 151.5 & 180.5 \\
\hline & & & & 0.15 & 94.7 & 104.9 \\
\hline & & & & 0.25 & 83.7 & 126.0 \\
\hline
\end{tabular}

During the milling operation of CFRP composite with uncoated inserts using different cutting speeds and feedrates, the hard and abrasive structure of carbon fibers induced flank wear on the cutting tools. This is attributed to the friction between the cutting tool and workpiece and an abrasive type wear mechanism [16, 19, 20].

The tool wear values obtained with different cutting speeds indicate that, the lowest occurred at $300 \mathrm{~m} / \mathrm{min}$ cutting speed and the wear level increased with decreasing cutting speed. The longest machining time (131.9 s) was belongs to the process with $100 \mathrm{~m} / \mathrm{min}$ cutting speed and $0.05 \mathrm{~mm} /$ tooth feedrate. Machining times were reduced with increasing cutting speed and feedrate values. The shortest machining time belongs to the cutting process with $300 \mathrm{~m} / \mathrm{min}$ and $0.25 \mathrm{~mm} /$ tooth feedrate. Machining time was increased with increasing cutting speed. Reduced machining times resulted in reduced wear levels, which increased the efficiency [21, 22].

The performance of the cutting tool used for machining of CFRP composite was evaluated on the basis of two testing conditions. These are; low machining 
conditions; $\quad V_{c}=100 \mathrm{~m} / \mathrm{min}, \quad f_{z}=0.05 \mathrm{~mm} /$ tooth and $a_{e}=1 \mathrm{~mm}$ cutting parameters and high machining conditions; $V_{c}=300 \mathrm{~m} / \mathrm{min}, f_{z}=0.25 \mathrm{~mm} /$ tooth and $a_{e}=1 \mathrm{~mm}$ cutting parameters. The resultant flank wear $\left(V_{B}\right)$ on the cutting edges of uncoated inserts used for machining of CFRP composite material was taken into consideration during evaluation of the process. The wear values of the cutting tools did not exceed the ISO standards for flank wear criteria which is $V_{B}>300 \mu \mathrm{m}$ [23]. The wear graphs obtained after the machining of the CFRP workpiece are given in Fig. 2 and Fig. 3.

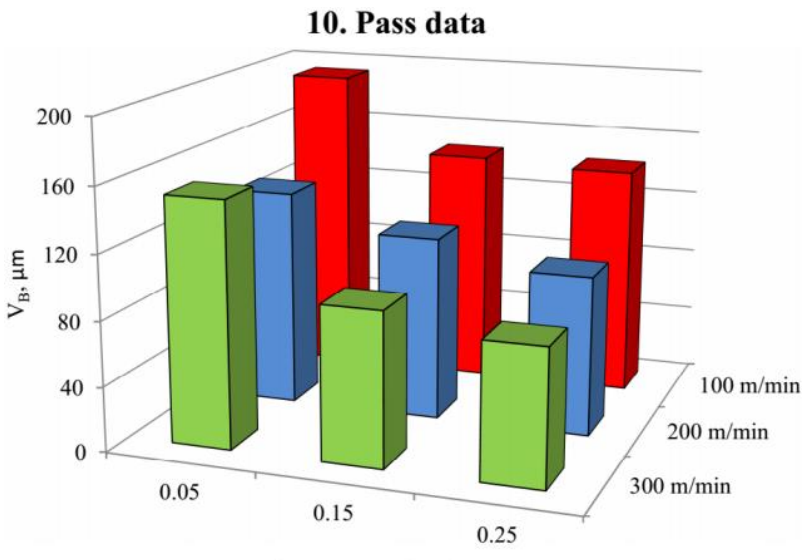

Feed rate, $f_{z}, \mathrm{~mm} /$ tooth

Fig. 2. Flank wear graph obtained from uncoated cutting tools' tenth pass at three different cutting speeds and feedrates

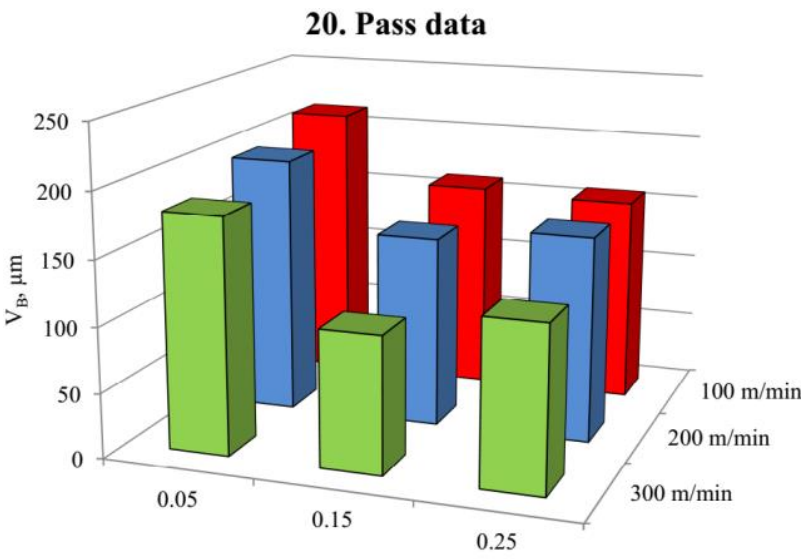

Feed rate, $f_{z}, \mathrm{~mm} /$ tooth

Fig. 3. Flank wear graph obtained from uncoated cutting tools' twentieth pass at three different cutting speeds and feedrates

As indicated by the wear graphs obtained after the tenth and twentieth passes with specified feedrates, wear values were reduced in connection with increasing feedrate. Accordingly, machining times and the corresponding wear levels decrease [24]. The highest wear value $(214.4 \mu \mathrm{m})$ was detected at $100 \mathrm{~m} / \mathrm{min}$ cutting speed and $0.05 \mathrm{~mm} /$ tooth feedrate, and the lowest wear value $(83.6 \mu \mathrm{m})$ was obtained at $300 \mathrm{~m} / \mathrm{min}$ cutting speed and $0.25 \mathrm{~mm} /$ tooth feedrate (Fig. 4 and Fig. 5).

Under low cutting conditions performed with low and high cutting parameters insignificant noise levels were observed, whereas under high cutting conditions, the effect of vibration is apparent. Flank wear was detected at $100 \mathrm{~m} / \mathrm{min}$ cutting speed and $0.05 \mathrm{~mm} /$ tooth feedrate as a result of the abrasive structure of the CFRP composite (Fig. 6).

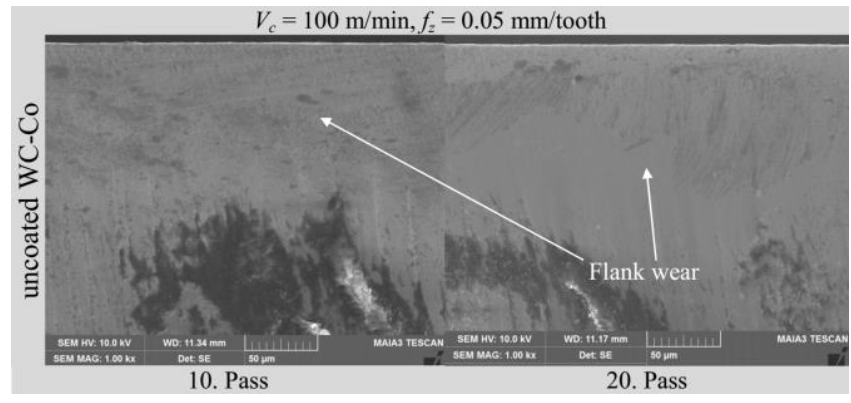

Fig. 4. SEM images after the tenth and twentieth passes of uncoated cutting tool

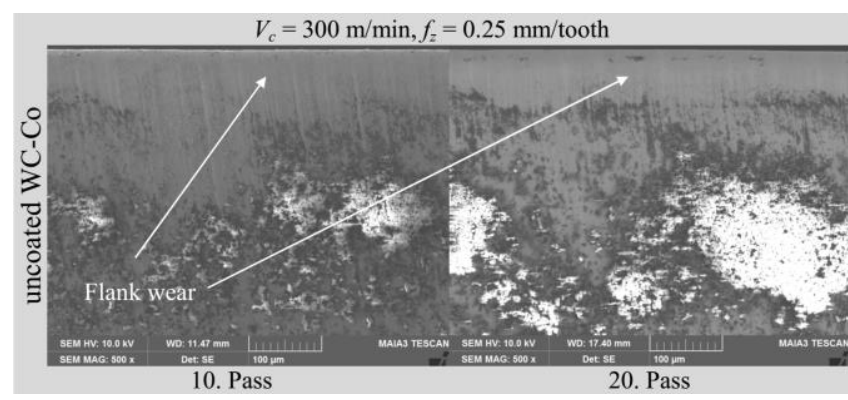

Fig. 5. SEM images after the tenth and twentieth passes of uncoated cutting tool

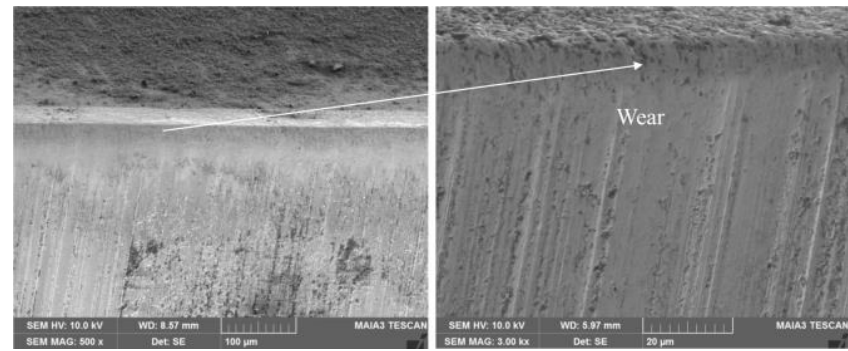

Fig. 6. SEM images of wear on uncoated cutting tools at $V_{c}=100$ $\mathrm{m} / \mathrm{min}, f_{z}=0.50 \mathrm{~mm} /$ tooth cutting parameters

As indicated by the wear values obtained with uncoated carbide inserts, wear values resulting from low cutting speed is higher than those obtained with high cutting speed. However, wear values obtained with low cutting conditions seem to differ from those obtained with high cutting conditions. At high cutting conditions $\left(V_{c}=300 \mathrm{~m} / \mathrm{min}\right.$ cutting speed and $f_{z}=0.25 \mathrm{~mm} /$ tooth feedrate) increased abrasive wear led to impaired surface quality for the machined workpiece. The cutting edge of the uncoated insert took on a polished-like appearance as a result of flank wear and built up edge (BUE) (adhesion of workpiece material on cutting tool) (Fig. 7). Nor Khairusshima et al [25] machined CFRP material at room temperature and chilled air conditions. They regarded tool wear as an important criteria emerging in machining, and reported high wear levels bot at room and chilled air temperature. They also reported that the cutting tool at chilled air conditions gained a smooth and shiny appearance arising from the abrasive characteristic of carbon fiber.

The workpiece was machined to $140 \mathrm{~mm}$ width, $6 \mathrm{~mm}$ height and $1 \mathrm{~mm}$ cutting width with uncoated carbide inserts using different cutting speed and feedrates. 

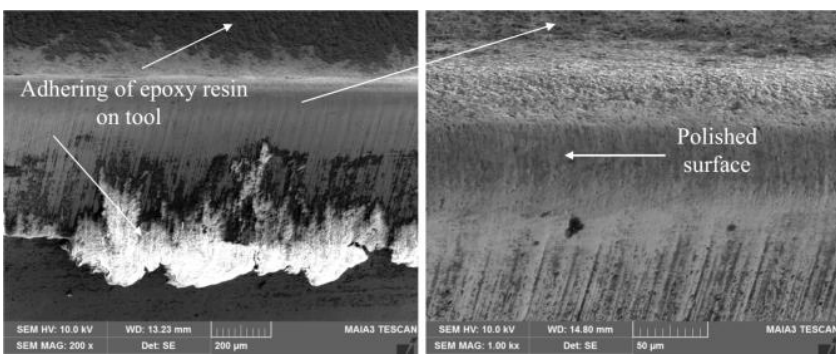

Fig. 7. SEM images of wear on uncoated cutting tools at $V_{c}=300 \mathrm{~m} / \mathrm{min}, f_{z}=0.25 \mathrm{~mm} /$ tooth cutting parameters

As the maximum value of chip thickness is dependent on the feedrate and cutting width, volume of the resultant chip (chip removal rate) was calculated as $840 \mathrm{~mm}^{3}$. Chip volumes obtained after 10 and 20 passes are given in Table 4.

Table 4. Chip removal rates obtained after 10th and 20th passes

\begin{tabular}{|c|c|}
\hline Number of passes & Chip removal rate, $\mathrm{mm}^{3}$ \\
\hline 10 & 8400 \\
\hline 20 & 16800 \\
\hline
\end{tabular}

The changes in tool wear at different cutting speeds and feedrates in relation with chip removal rates are given in Fig. 8-Fig. 10.

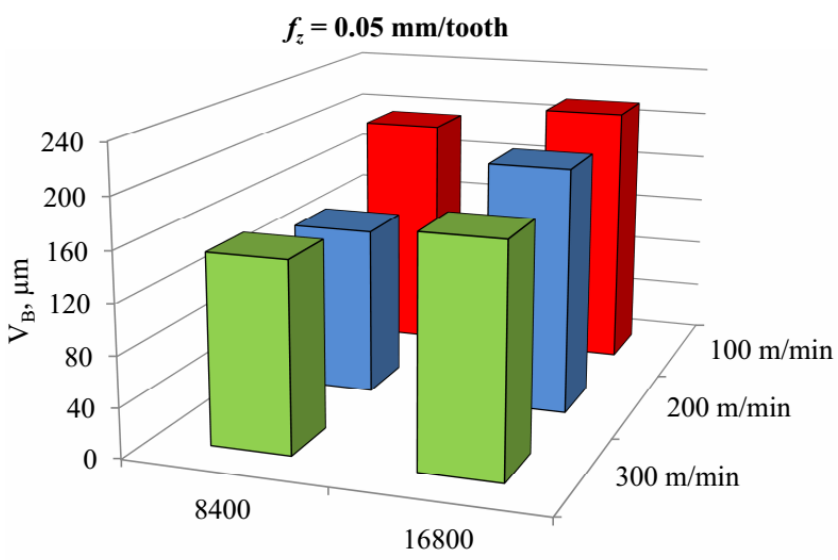

Chip removal rate, $\mathrm{mm}^{3}$

Fig. 8. Chip removal rates obtained at three different cutting speeds and $0.05 \mathrm{~mm} /$ tooth feed rate after 10th and 20th passes

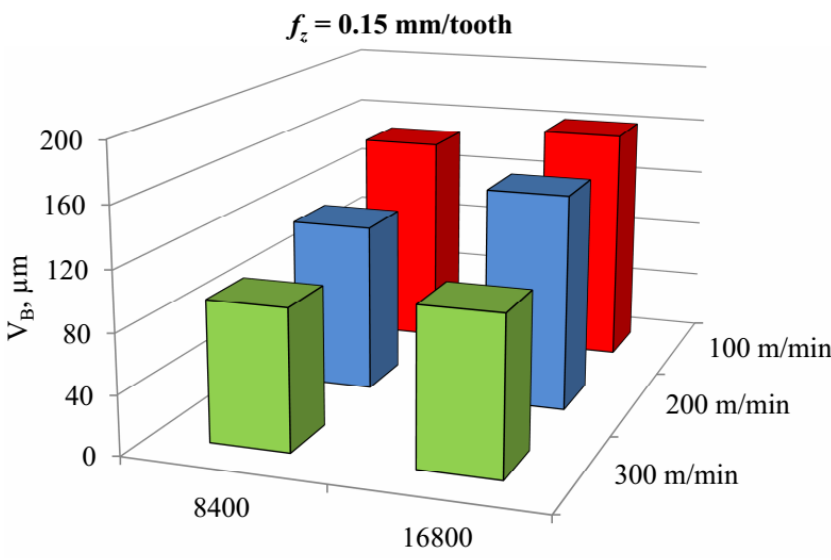

Chip removal rate, $\mathrm{mm}^{3}$

Fig. 9. Chip removal rates obtained at three different cutting speeds and $0.15 \mathrm{~mm} /$ tooth feed rate after 10 th and 20 th passes

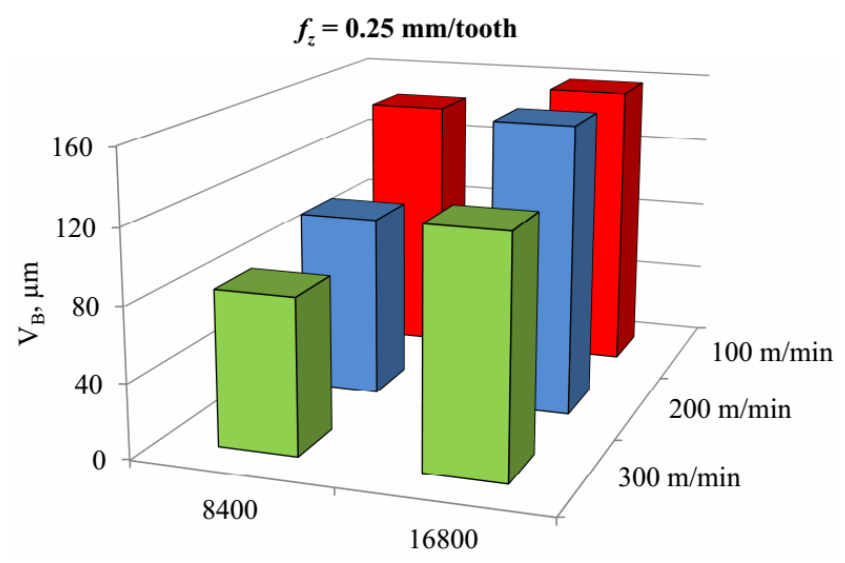

Chip removal rate, $\mathrm{mm}^{3}$

Fig. 10. Chip removal rates obtained at three different cutting speeds and $0.25 \mathrm{~mm} /$ tooth feedrate after 10th and 20th passes

In the graphs, chip removal rates are given with relation to the number of machining passes. Increased wear values were observed as a result of the effect of the heat and friction at cutting tool-workpiece interface. The heat arising from machining of CFRP material softens the matrix material which weakens the adherence between fiber reinforcements, thus increasing tool wear [26].The highest wear value was detected with $0.05 \mathrm{~mm} /$ tooth feedrate in machining of CFRP composite with uncoated carbide insert. Wear values were found to decrease with increasing cutting speed, which was also associated with the machining time. Increasing feedrate and cutting speeds were found to reduce the machining times.

\section{CONCLUSIONS}

The tool wear results obtained from contour milling of CFRP composite material with uncoated carbide cutting tool, using varying cutting speeds and feedrates, are given below

1. The wear images of uncoated inserts show that, the abrasive characteristic of CFRP composite material resulted in flank wear on uncoated inserts.

2. Tool wear results related with the change in feedrate indicate that the lowest wear was observed at $0.25 \mathrm{~mm} /$ tooth feedrate as a result of the machining times.

3. Tool wear results of CFRP composite related with the change in cutting speed indicate that the lowest wear was observed with $300 \mathrm{~mm} / \mathrm{min}$ cutting speed as a result of the machining times.

4. SEM images of the worn uncoated inserts show that, the lowest wear values were obtained at $300 \mathrm{~m} / \mathrm{min}$ cutting speed and $0.25 \mathrm{~mm} /$ tooth feedrate.

5. Chip removal rates increased with increasing number of machining passes.

\section{Acknowledgments}

This investigation was financially supported by Bartin University (Grant Number:BAP.2016-FEN-C-004). 


\section{REFERENCES}

1. Teti, R. Machining of Composite Materials CIRP AnnalsManufacturing Technology 51 (2) 2002: pp. 611-634. https://doi.org/10.1016/S0007-8506(07)61703-X

2. Lee, Y., Park, J., Hong, J., Kim, S. A Study of Bond of Structural Timber and Carbon Fiber Reinforced Polymer Plate Materials Science (Medžiagotyra) 21 (4) 2015: pp. $563-567$. http://dx.doi.org/10.5755/j01.ms.21.4.9702

3. Sun, W., Zhu, Q., He, W. Experimental Study of ConcreteFilled Carbon Fiber Reinforced Polymer Tube with Internal Reinforcement Under Axially Loading Materials Science (Medžiagotyra) 20 (4) 2014: pp. 493-497. http://dx.doi.org/10.5755/j01.ms.20.4.6035

4. Karino, K. Cutting Processing Handbook of Difficult Cutting Materials and New Materials, Published by Kogyo Chosakai Publishing Co., Ltd 2002: pp. 11-15.

5. Hagino, M., Inoue, T. Effect of Carbon Fiber Orientation and Helix Angle on CFRP Cutting Characteristics by EndMilling International Journal of Automation Technology 7 (3) 2013: pp. 292-299.

6. Tamin, M.N. Damage and Fracture of Composite Materials and Structures. Springer, Heidelberg, Germany, 2012: Vol. 17.

7. Rajasekaran, T., Vinayagam, B.K., Palanikumar, K., Prakash, S. Influence of Machining Parameters on Surface Roughness and Material Removal Rate in Machining Carbon Fiber Reinforced Polymer Material Frontiers in Automobile and Mechanical Engineering 2010: pp. 75-80. http://dx.doi.org/10.1109/FAME.2010.5714801

8. Sheikh-Ahmad, J.Y., Dhuttargaon, M., Cheraghi, H. New Tool Life Criterion for Delamination Free Milling of CFRP The International Journal of Advanced Manufacturing Technology $92(5-8)$ 2017: pp. $2131-2143$. https://doi.org/10.1007/s00170-017-0240-2

9. Pecat, O., Rentsch, R., Brinksmeier, and E. Influence of Milling Process Parameters on the Surface Integrity of CFRP Procedia CIRP 1 2012: pp. 466-470. https://doi.org/10.1016/j.procir.2012.04.083

10. Bhatnacar, N., Ramakrishnan, N., Naik, N.K., Komanduri, R. On the Machining of Fiber Reinforced Plastic (FRP) Composite Laminates International Journal of Machine Tools Manufacture 35 (5) 1995: pp. 701-716. https://doi.org/10.1016/0890-6955(95)93039-9

11. Patel, P., Chaudhary, V., Patel, K., Gohil, P. Milling of Polymer Matrix Composites: A Review International Journal of Applied Engineering Research $13(10)$ 2018: pp. 7455-7465.

12. Ahmet, C. Effect of Edge Trimming Parameters on Surface Quality of Carbon Fiber Reinforced Polymer Composites Afyon Kocatepe University Journal of Sciences and Engineering 17 2017: pp. 302-311. https://doi.org/10.5578/fmbd.54017

13. Rusinek, R. Cutting Process of Composite Materials: An Experimental Study International Journal of Non-Linear Mechanics 45 (4) 2010: pp. 458-462. https://doi.org/10.1016/j.ijnonlinmec.2010.01.004

14. Karpat, Y., Polat, N. Mechanistic Force Modeling for Milling of Carbon Fiber Reinforced Polymers with Double
Helix Tools CIRP Annals-Manufacturing Technology 62 (1) 2013: pp. $95-98$.

https://doi.org/10.1016/j.cirp.2013.03.105

15. Chatelain, J.F., Zaghbani, I., Monier, J. Effect of Ply Orientation on Roughness for the Trimming Process of CFRP Laminates International Journal of Mechanical, Aerospace, Industrial, Mechatronic and Manufacturing Engineering 6(8) 2012: pp. 1516-1522. https://doi.org/10.1016/j.rcim.2016.05.004

16. Nor Khairusshima, M.K.,

Che Hassan, C.H., Jaharah, A.G., Akim, N.A. Tool Wear and Surface Roughness on Milling Carbon Fiber-Reinforced Plastic Using Chilled Air Journal of Asian Scientific Research 2 (11) 2012: pp. 593-598.

17. Koplev, A., Lystrup, A.A., Vorm, T. The Cutting Process, Chips, and Cutting Forces in Machining CFRP Composites 14 (4) 1983: pp. $371-376$. https://doi.org/10.1016/0010-4361(83)90157-X

18. Jahanmir, S., Ramulu, M., Koshy, P. Machining of Ceramics and Composites. New York: Marcel Dekker, 1999.

19. Hocheng, H., Puw, H.Y., Huang, Y. Preliminary Study on Milling of Unidirectional Carbon Fibre-Reinforced Plastics Composites Manufacturing 4 (2) 1993: pp. 103-108. https://doi.org/10.1016/0956-7143(93)90077-L

20. Madhavan, V., Lipczynski, G., Lane, B., Whitenton, E. Fiber Orientation Angle Effects in Machining of Unidirectional CFRP Laminated Composites Journal of Manufacturing Processes 20 2015: pp. 431-442. https://doi.org/10.1016/j.jmapro.2014.06.001

21. Gaitonde, V.N., Karnik, S.R., Rubio, J.C., Correia, A.E., Abrao, A.M., Davim, J.P. Analysis of Parametric Influence on Delamination in High-Speed Drilling of Carbon Fiber Reinforced Plastic Composites Journal of Materials Processing Technology 203 (1-3) 2008: pp. 431-438. https://doi.org/10.1016/j.jmatprotec.2007.10.050

22. Lin, S.C., Chen, I.K. Drilling Carbon Fiber-Reinforced Composite Material at High Speed Wear $194(1-2)$ 1996: pp. $156-162$. https://doi.org/10.1016/0043-1648(95)06831-7

23. Astakhov, V.P. The Assessment of Cutting Tool Wear International Journal of Machine Tools and Manufacture 44 (6) 2004: pp. 637-647. https://doi.org/10.1016/j.ijmachtools.2003.11.006

24. Astakhov, V.P. Effects of the Cutting Feed, Depth of Cut, and Workpiece (Bore) Diameter on the Tool Wear Rate The International Journal of Advanced Manufacturing Technology 34 (7-8) 2007: pp. 631-640. https://doi.org/10.1007/s00170-006-0635-y

25. Khairusshima, M.N., Hassan, C.C., Jaharah, A., Amin, A., Idriss, A.M. Effect of Chilled Air on Tool Wear and Workpiece Quality During Milling of Carbon Fibre-Reinforced Plastic Wear $302(1-2)$ 2013: pp. $1113-1123$. https://doi.org/10.1016/j.wear.2013.01.043

26. Jia, Z., Fu, R., Wang, F., Qian, B., He, C. Temperature Effects in End Milling Carbon Fiber Reinforced Polymer Composites Polymer Composites 39 (2) 2018: pp. 437-447. https://doi.org/10.1002/pc.23954 